\title{
Effect of protein restriction in insulin dependent diabetics at risk of nephropathy
}

\author{
DAVID COHEN， ROSEMARY DODDS， GIANCARLO VIBERTI
}

\begin{abstract}
Persistent proteinuria is strongly associated with increased mortality in insulin dependent diabetes, and risk of this condition can be predicted many years in advance by subclinical increases in albumin excretion rate (microalbuminuria). Eight normotensive insulin dependent diabetics with microalbuminuria who had overnight albumin excretion rates of between 15 and $200 \mu \mathrm{g} / \mathrm{min}$ underwent a three week randomised crossover study of their normal protein diet (median 92 (range 55-117) g/day) and a low protein diet (47 (38-57) g/day). Both diets were isoenergetic, and the low protein diet was supplemented with calcium and phosphate. Median overnight albumin excretion rate fell from $23.0(15 \cdot 0-170 \cdot 1) \mu \mathrm{g} / \mathrm{min}$ during the normal diet to $15.4(4 \cdot 1-97 \cdot 8)$ $\mu \mathrm{g} / \mathrm{min}$ during the low protein diet. No consistent change was found in urinary excretion of $\beta_{2}$ microglobulin during the two diets. The reduction in albumin excretion rate was accompanied by a significant fall in median glomerular filtration rate and fractional renal clearance of albumin. Kidney volume remained unchanged. There were no significant changes in glycaemic control or arterial blood pressure.

In these few patients restriction of dietary protein had a beneficial effect on microalbuminuria, independent of changes in glucose concentrations and arterial blood pressure.
\end{abstract}

\section{Introduction}

Persistent proteinuria in insulin dependent diabetics is associated with mortality up to 100 times that of the non-diabetic population. By contrast, in diabetics without persistent proteinuria relative mortality is only about two to four. ' Subclinically raised albumin excretion rates ranging from 15 to $200 \mu \mathrm{g} / \mathrm{min}$ (microalbuminuria) predict clinical, nephropathy in insulin dependent diabetics..$^{2-4}$

\footnotetext{
Unit for Metabolic Medicine, United Medical and Dental Schools, Guy's Campus, London SE1 9RT

DAVID COHEN, MB, MRCP, research registrar

ROSEMARY DODDS, BSC, SRD, research dietitian

GIANCARLO VIBERTI, MD, MRCP, senior lecturer and honorary consultant

Correspondence and requests for reprints to: Dr Viberti.
}

Treatment that normalises this early marker of disease may prevent or postpone persistent clinical proteinuria and therefore reduce premature death.

Intensified insulin treatment and strict glycaemic control have been shown to reduce albumin excretion in diabetics with microalbuminuria. ${ }^{56}$ The effect of glycaemic control remains controversial, however, and recent work failed to show a reduction in the fractional clearance of albumin after long term improved metabolic control in insulin dependent diabetics selected for having persistent (that is, in at least two out of three determinations) subclinically raised 24 hour albumin excretion rates. ${ }^{78}$ One of several possible reasons for these different findings is that "persistent" microalbuminuria represents a stage of renal disease in diabetes already partly unresponsive to metabolic correction. It is therefore important to test alternative therapeutic strategies.

Dietary protein has a profound effect on kidney function and has a role in the progression of renal failure in various renal diseases.9-11 We therefore investigated the effect of restricting dietary protein intake on albuminuria, glomerular filtration rate, and kidney size in a group of insulin dependent diabetics with persistent microalbuminuria.

\section{Patients and methods}

We studied eight normotensive insulin dependent diabetics (six men, two women; mean age 38.7 (range 22-57) years) without clinical proteinuria (mean duration of diabetes 19.6 (11-29) years). They were selected because the urinary albumin excretion rate in a timed overnight sample was $15-200 \mu \mathrm{g} / \mathrm{min}$ on three successive occasions during a six week run in period: All patients were within $10 \%$ of their ideal body weight (Metropolitan Life Insurance Co tables, 1959) and taking no drugs other than insulin. They did not have neuropathy, known cardiac or renal disease, or urinary tract infection. Three had background retinopathy and one proliferative retinopathy.

After baseline assessment patients were randomly allocated to take in turn a low protein diet or their usual diet for three weeks. Five patients received the low protein diet first and three their usual diet first. To prevent carryover effects there was a one week interval of normal diet between the two experimental periods. The low protein diet provided $40 \mathrm{~g}$ mixed protein daily. It was designed to be isoenergetic with the usual diabetic diet, with $35 \%$ of the energy coming from fat and $55-60 \%$ from carbohydrate. This required the use of special low protein carbohydrate sources (GF Dietary Supplies, Stanmore, Middlesex, UK). To maintain similar fibre intakes during the low protein diet patients were encouraged to eat sources of 
vegetable fibre poor in protein. Calcium (mean 425 (range 200-800) $\mathrm{mg} /$ day) and phosphate (mean 500 (range $250-750$ ) $\mathrm{mg} /$ day) tablets were prescribed to supplement the low protein diet to the same intake as the usual diet.

A nutritionist assessed dietary intake initially and during each experimental period by interview and a three day, weighed food record. A 24 hour urine collection for measurement of urea excretion was made during each of the last two weeks of each dietary period to obtain an objective measure of protein intake and compliance. The mean of the two collections was used to calculate protein intake from the urinary urea nitrogen (UUN) and an estimated non-urea nitrogen (NUN) of $31 \mathrm{mg} / \mathrm{kg} / \mathrm{day}^{12}$ : UUN+NUN=nitrogen intake $\left(I_{n}\right) ; I_{n} \times 6.25=$ protein intake in $g /$ day (assuming constant nitrogen balance). ${ }^{13}$ Twenty four hour urinary excretion of creatinine, calcium, and phosphate and plasma urea and albumin concentrations were measured at the same time. Patients were weighed unshod in indoor clothes at the end of each dietary period.

During both dietary periods the patients collected weekly seven point blood glucose profiles (BM-Test Glycemie 20-800), the samples being taken before and two hours after main meals and at bedtime; the profiles were immediately posted to our laboratory and read by a Reflolux meter. Not all patients managed to perform three full seven point profiles, but the same number of samples at the same time points during the day were compared for each patient. Sample numbers varied from 10 to 21 with each diet. Mean blood glucose concentration for each patient was calculated as the mean of all relevant samples during each dietary period.

At the end of each dietary period fructosamine concentration, an integrated index of short term glycaemic control,${ }^{14}$ was measured by CobasBio autoanalyser (normal range in our laboratory $1.8-2.7 \mathrm{mmol} / \mathrm{l}$ ), glomerular filtration rate by clearance of edetic acid labelled with chromium- $51,{ }^{15}$ and kidney volume by ultrasonography. ${ }^{16}$ Normal ranges for glomerular filtration rate and kidney volume in our laboratory are $84-135 \mathrm{ml} / \mathrm{min} /$ $1.73 \mathrm{~m}^{2}$ and $210-298 \mathrm{ml} / 1.73 \mathrm{~m}^{2}$ respectively. ${ }^{15}$ Precisely timed (to the nearest minute) overnight urine collections were made on the last two days of the two dietary periods for measurement of urinary albumin concentration by radioimmunoassay ${ }^{18}$ and $\beta_{2}$ microglobulin by $\beta_{2}$-Micro RIA (Pharmacia Diagnostics, Uppsala, Sweden). The average of the two resuits was used for calculations. A Vickers multichannel analyser was used to measure concentrations of albumin in plasma and creatinine, calcium, phosphate, and urea in urine and plasma. Fractional clearance of albumin was calculated by dividing the albumin clearance (UV/P), where $U$ and $P$ were the urinary and plasma albumin concentrations respectively and $\mathrm{V}$ the urine flow, by the glomerular filtration rate.

At the end of each dietary period blood pressure (phase I/V) was measured to the nearest $2 \mathrm{~mm} \mathrm{Hg}$ on two occasions three minutes apart, firstly with the patient supine after five minutes' rest and then immediately after standing, by the same observer (DC) using a random zero mercury sphygmomanometer (Hawksley UK); the readings were then averaged.

All subjects gave informed consent to the study, which was approved by the hospital ethical committee.

Analyses were performed with the Wilcoxon test for paired data. Albumin and $\beta_{2}$ microglobulin excretion rates were logarithmically transformed before analysis because of their positively skewed distribution. Results are given as medians with ranges. Significance was taken as $p<0.05$.

\section{Results}

Table I shows dietary data. The median protein intake assessed by the three daily weighed food records was similar to that calculated from urinary urea excretion. Both measures confirmed a significantly lower protein intake in all patients during the low protein diet, which approached that prescribed. The significantly lower urea excretion and plasma urea concentration during the low protein diet supported the patients' compliance. Energy intake was unchanged during the low protein diet because of a considerable increase in carbohydrate. Fat intake fell during the low protein diet but fibre intake was not different. Despite supplementation urinary excretion of phosphate and calcium was lower during the low protein diet; creatinine excretion remained unchanged. There was no change in body weight or plasma albumin concentration.

Albumin excretion rate was lower in all patients during the low protein diet $(15 \cdot 4(4 \cdot 1-97 \cdot 8) \mu \mathrm{g} / \mathrm{min})$ compared with the normal diet $(23.0$ $(15 \cdot 0-170 \cdot 1) \mu \mathrm{g} / \mathrm{min})(p=0 \cdot 01)$ (fig 1$)$. In contrast, there were no consistent changes in $\beta_{2}$ microglobulin excretion during the two diets (59.0 (35.9. $166 \cdot 2) \mathrm{ng} / \mathrm{min}$ during the normal diet $v 82 \cdot 1(9 \cdot 8-140 \cdot 0) \mathrm{ng} / \mathrm{min}$ during the low protein diet). Glomerular filtration rate, measured in seven patients, fell from $109(76-135) \mathrm{ml} / \mathrm{min} / 1 \cdot 73 \mathrm{~m}^{2}$ during the normal diet to 100 $(72-114) \mathrm{ml} / \mathrm{min} / 1 \cdot 73 \mathrm{~m}^{2}$ during the low protein diet $(p=0.02)$ (fig 2$)$. Fractional clearance of albumin fell significantly from $5 \cdot 5(2 \cdot 7-19 \cdot 7) \times 10^{-6}$ during the normal diet to $3.4(0.9-6.9) \times 10^{-6}$ during the low protein diet $(p=0.02)$ (table II). Kidney volume, measured for technical reasons in only
TABLE I-Dietary data for eight insulin dependent diabetics with microalbuminuria taking their normal diet and a low protein diet. Values are medians (and ranges)

\begin{tabular}{|c|c|c|c|}
\hline & $\begin{array}{c}\text { Normal } \\
\text { diet }\end{array}$ & $\begin{array}{l}\text { Low protein } \\
\text { diet }\end{array}$ & Significance \\
\hline $\begin{array}{l}\text { Energy intake (MJ/day) } \\
\text { Protein intake (g/day): }\end{array}$ & $9 \cdot 3(6 \cdot 6-12 \cdot 6)$ & $8 \cdot 9(5 \cdot 2-10 \cdot 4)$ & NS \\
\hline From food records & $92(55-117)$ & $47(38-57)$ & $\begin{array}{l}p<0.01 \\
p<0.01\end{array}$ \\
\hline $\begin{array}{l}\text { From urea excretion } \\
\text { Carbohydrate intake (g/day) }\end{array}$ & $\begin{array}{c}94(42-137) \\
210(148-288)\end{array}$ & $\begin{array}{c}51(29-87) \\
290(176-340)\end{array}$ & $\begin{array}{l}p<0.01 \\
p<0.01\end{array}$ \\
\hline Fat intake (g/day) & $119(72-154)$ & $94(56-111)$ & $\mathrm{p}<0.05$ \\
\hline Fibre intake (g/day) & $22(12-38)$ & $26(18-41)$ & NS \\
\hline Urinary urea $(\mathrm{mmol} / 24 \mathrm{~h})$ & $482(161-789)$ & $204(88-402)$ & $p<0.01$ \\
\hline Urinary creatinine $(\mathrm{mmol} / 24 \mathrm{~h})$ & $13 \cdot 4(9 \cdot 0-19 \cdot 2)$ & $11 \cdot 5(9 \cdot 8-23.9)$ & NS \\
\hline Urinary calcium (mmol/24 h) & $4 \cdot 8(1 \cdot 9-8 \cdot 6)$ & $2 \cdot 9(1 \cdot 1-5 \cdot 6)$ & $p<0.05$ \\
\hline Urinary phosphate $(\mathrm{mmol} / 24 \mathrm{~h})$ & $38 \cdot 2(17 \cdot 6-46 \cdot 6)$ & $26 \cdot 7(11 \cdot 9-38 \cdot 3)$ & $\mathrm{p}<0.02$ \\
\hline Plasma urea $(\mathrm{mmol} / \mathrm{l})$ & $6 \cdot 9(4 \cdot 4-7 \cdot 9)$ & $3 \cdot 7(2 \cdot 5-6 \cdot 9)$ & $\mathrm{p}<0.02$ \\
\hline Plasma albumin $(\mathrm{g} / \mathrm{l})$ & $39 \cdot 6(35 \cdot 4-44 \cdot 8)$ & $40 \cdot 0(35 \cdot 5-43 \cdot 5)$ & NS \\
\hline Body weight $(\mathbf{k g})$ & $73 \cdot 7(56 \cdot 2-90 \cdot 0)$ & $74 \cdot 2(56 \cdot 7-89 \cdot 1)$ & NS \\
\hline
\end{tabular}

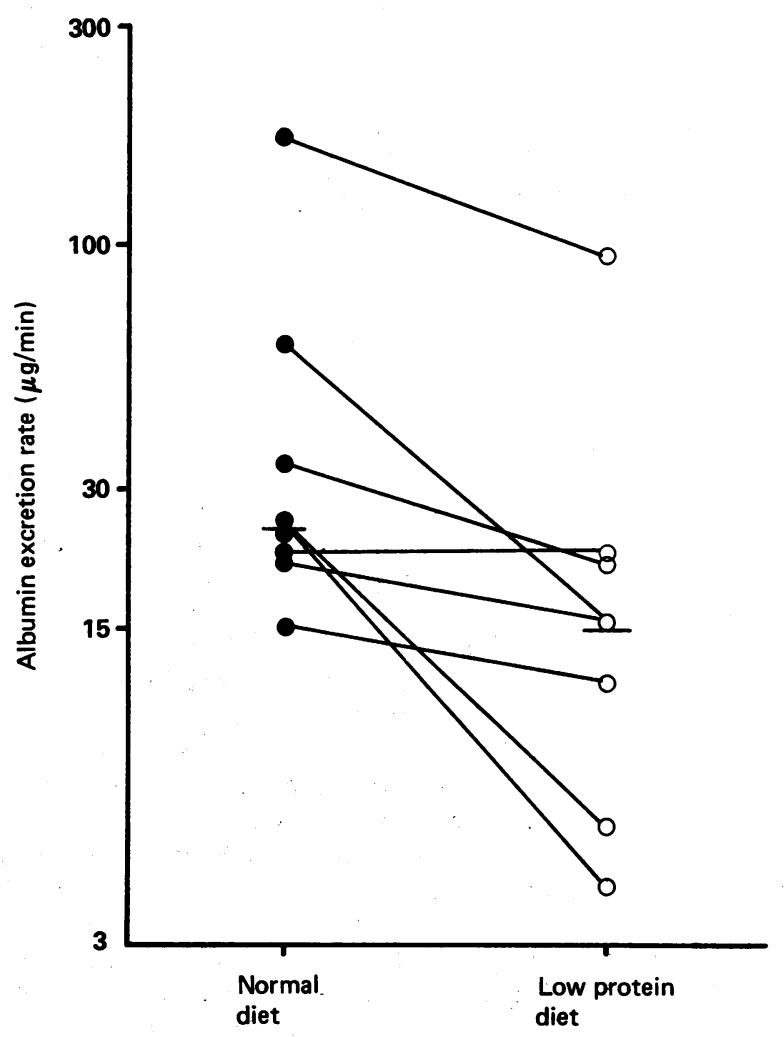

FIG 1-Albumin excretion rates during a normal diet and low protein diet in eight insulin dependent diabetics with microalbuminuria. Horizontal bars indicate the median values $(p=0.01)$.

six patients, showed no significant change $\left(338(279-431) \mathrm{ml} / 1 \cdot 73 \mathrm{~m}^{2}\right.$ during the normal diet and $334(262-450) \mathrm{ml} / 1 \cdot 73 \mathrm{~m}^{2}$ during the low protein diet). Four patients had nephromegaly (that is, kidney volume $>300 \mathrm{ml} / 1 \cdot 73 \mathrm{~m}^{2}$ ). Blood glucose concentration (fig 3), fructosamine concentration, and arterial pressure (table III) were not significantly different during the two diets. Three patients were advised to reduce their insulin dosage by up to $10 \mathrm{U} /$ day during the low protein diet to maintain comparable glycaemic control.

\section{Discussion}

In this small group of patients a diet restricted in protein significantly reduced microalbuminuria, which is an important risk factor for persistent proteinuria and clinical nephropathy in insulin dependent diabetes. This effect is consistent with the results reported in non-diabetic patients with heavier proteinuria and overt renal disease $\mathrm{e}^{1019}$ and was obtained independently of changes in blood glucose concentration and blood pressure, which are two factors that influence albumin excretion rate in diabetes. ${ }^{5820-23}$ The low protein diet not only achieved a significant reduction in protein intake but also lowered fat and phosphate intakes, despite supplementation, and increased carbohydrate intake. Although any 
or all of these changes may have contributed to the observed effect on albuminuria, ${ }^{24}$ there is convincing evidence that protein and possibly phosphate intake may be the main determinants. ${ }^{2526}$ Several studies in animal models of renal disease support the idea that low protein intake has a beneficial effect on albuminuria and renal lesions seen on histological examination. ${ }^{97}$

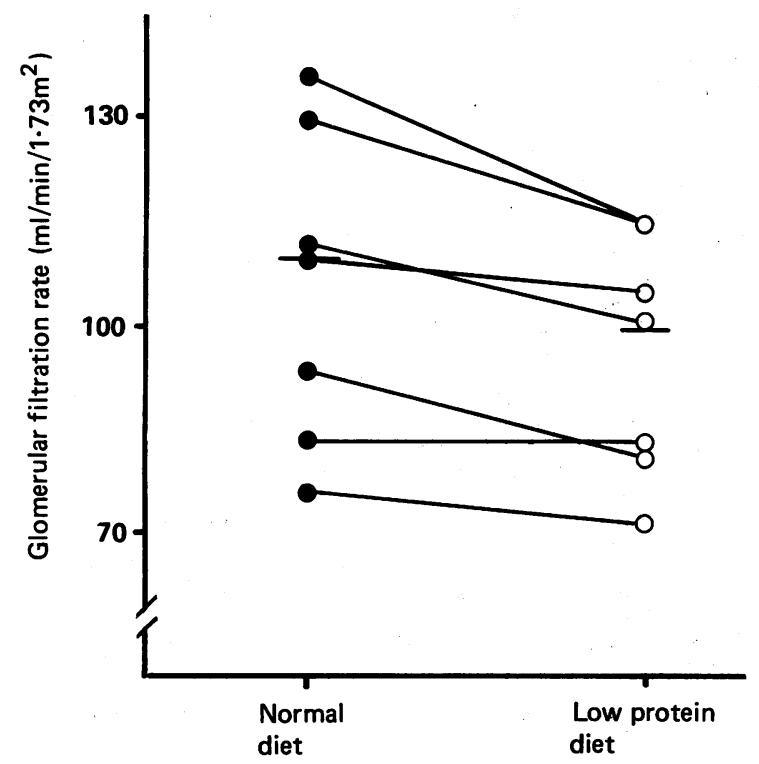

FIG 2-Glomerular filtration rate, measured by clearance of edetic acid labelled with chromium-51, during normal diet and low protein diet in seven insulin dependent diabetics with microalbuminuria. Horizontal bars indicate median values $(p=0.02)$.

TABLE II-Fractional clearance of albumin $\left(\times 10^{-6}\right)$ in seven insulin dependent diabetics with microalbuminuria during normal and low protein diets

\begin{tabular}{ccc}
\hline Case No & Normal diet & Low protein diet \\
\hline 1 & $3 \cdot 8$ & 3.4 \\
2 & $4 \cdot 6$ & 0.9 \\
3 & $2 \cdot 7$ & $2 \cdot 3$ \\
4 & $9 \cdot 7$ & 6.9 \\
5 & $5 \cdot 5$ & $1 \cdot 4$ \\
6 & $19 \cdot 7$ & $5 \cdot 9$ \\
7 & 6.9 & 6.8 \\
\hline Median (range) & $5.5(2 \cdot 7-19 \cdot 7)$ & $3.4(0.9-6.9)^{\star}$ \\
\hline${ }_{\mathrm{p}=0.02 .}$ & & \\
\end{tabular}

There are several possible explanations for the reduction in albumin excretion rate. It may have fallen as a result of a reduced load of filtered albumin: although plasma albumin concentration was not changed, the concomitant fall in glomerular filtration rate might have produced this effect. The lower fractional clearance of albumin during the low protein diet suggests, however, that the change in albumin excretion reflected changes in the ultrafiltration properties of the glomerulus (changes in the selective permeability of the membrane or haemodynamic changes, or both). This is consistent with work in diabetic animals, in which the reduced albuminuria after dietary protein restriction has been associated with reduced intraglomerular pressures. ${ }^{27}$ These modifications of renal function prevented the renal lesions of diabetes in rats. ${ }^{27}$

Other workers have suggested that naturally occurring cationic polyamino acids generated by the digestion of animal proteins, especially meat, may neutralise the anionic glomerular charge and facilitate transglomerular flux of anionic albumin..$^{28}$ Reduced generation of these polycations by a low protein intake may therefore help reduce albuminuria. The quantitative aspects of
TABLE III-Serum fructosamine concentration and systolic and diastolic blood pressures during normal and low protein diets in eight insulin dependent diabetics with microalbuminuria. Values are medians (and ranges)

\begin{tabular}{lccc}
\hline & Normal diet & Low protein diet & Significance \\
\hline Fructosamine (mmol/l) & $3 \cdot 25(3 \cdot 1-3 \cdot 8)$ & $3 \cdot 13(2 \cdot 8-3 \cdot 5)$ & NS \\
Systolic blood pressure $(\mathrm{mm} \mathrm{Hg})$ & $126(105-136)$ & $128(94-142)$ & NS \\
Diastolic blood pressure $(\mathrm{mm} \mathrm{Hg})$ & $75(71-88)$ & $74(64-80)$ & NS \\
\hline
\end{tabular}
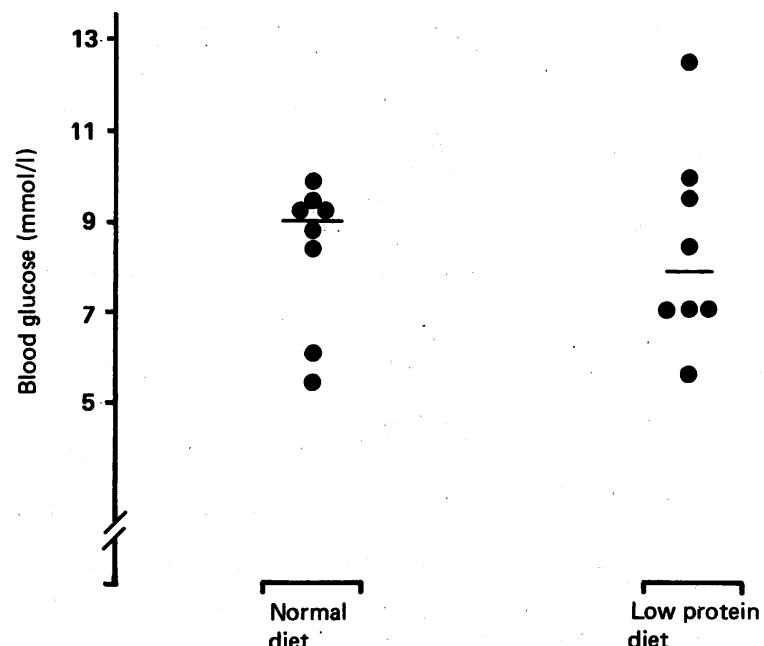

FIG 3-Individual mean blood glucose concentrations in samples collected at home during normal diet and low protein diet in eight insulin dependent diabetics with microalbuminuria. Horizontal bars indicate the group median.

this putative phenomenon have not, however, been elucidated. Alternatively, the fall in albumin excretion may have been the result of changes in tubular reabsorption of protein. This, however, is unlikely because the stability of $\beta_{2}$ microglobulin excretion, a marker of tubular function, ${ }^{29}$ suggests that the tubular handling of proteins remained unchanged.

Kidney volume was not reduced by three weeks of the low protein diet. Enlargement of the kidney can be prevented in diabetes by strict metabolic control, ${ }^{30}$ but reversal of nephromegaly has proved difficult in both diabetic animals and man. ${ }^{15} 3132$ In man three weeks of a low protein diet may not be long enough to affect kidney size. Alternatively, the reduction in dietary protein may not have been large enough to produce an effect or may have affected selected renal structures such as glomeruli, which are a fairly small part of total kidney volume. ${ }^{33}$ The dissociation between the effect of a low protein diet on renal function and renal size is similar to that seen with strict glycaemic control ${ }^{\text {is } 31}$ and suggests that important functional changes take place in the kidney in the short term without changes in total renal volume.

Our findings provide an alternative approach to managing microalbuminuria in diabetes. Strict blood glucose control is not without risk ${ }^{5435}$ and may not be totally successful ${ }^{7}$; similarly, the value of treating the subclinical increase in arterial pressure that may accompany microalbuminuria ${ }^{3422}$ is still uncertain. ${ }^{36} 37$ Diets containing roughly $45 \mathrm{~g}$ protein have no untoward long term nutritional effects in patients with established renal disease. ${ }^{102538}$ The short term efficacy of the protein restricted diet in our eight diabetics at risk of nephropathy should encourage more extensive investigations into the long term effect on renal function and structure. Protein restriction may complement other preventive treatment in these patients.

We thank Graham Scott for skilled technical help, the department of nuclear medicine for measurements of glomerular filtration rate, Dr Andrew Saunders for measurements of kidney volume, and Professor Harry Keen for help and encouragement. DC is a Pfizer research fellow, RD is supported by GF Dietary Supplies Ltd, and the work was partly supported by a grant from the National Kidney Research Fund. 


\section{References}

1 Borch-Johnsen K, Andersen PK, Deckert T. The effect of proteinuria on relative mortality in type I (insulin-dependent) diabetes mellitus. Diabetologia 1985;28:590-6

2 Viberti GC, Hill RD, Jarrett RJ, Argyropoulos A, Mahumud U, Keen H. Microalbuminuria as a predictor of clinical nephropathy in insulin dependent diabetes mellitus. Lancet 1982;i:1430-2.

3 Mogensen CE, Christensen CK. Predicting diabetic nephropathy in insulin-dependent patients. N Engl f Med 1984;311:89-93.

4 Mathiesen ER, Oxenbøll D, Johansen K, Svendsen PA, Deckert T. Incipient nephropathy in type I (insulin-dependent) diabetes. Diabetologia 1984;26:406-10.

5 Kroc Collaborative Study Group. Blood glucose control and the evolution of diabetic retinopathy and microalbuminuria. $N$ Engl f Med 1984;311:365-72.

6 Viberti GC, Pickup JC, Jarrett RJ, Keen H. Effect of control of blood glucose on urinary excretion of albumin and $\beta_{2}$ microglobulin in insulin-dependent diabetes. $N$ Engl f Med 1979;300: 638-41.

7 Feldt-Rasmussen B, Mathiesen ER, Hegedus L, Deckert T. Kidney function during twelve months of strict metabolic control in insulin-dependent diabetic patients with incipient nephropathy. N Engl f Med 1986;314:665-70.

8 Feldt-Rasmussen B, Mathiesen ER, Deckert T. Effect of two years of strict metabolic control on progression of incipient nephropathy in insulin-dependent diabetes. Lancet 1986;ii:1300-4.

9 Brenner BM, Meyer TW, Hostetter TH. Dietary protein intake and the progressive nature of kidney disease. N Engl f Med 1982;307:652.

10 Rosman JB, Ter Wee PM, Meijer S, Piers-Becht TPM, Shuter WJ, Donker AJM. Prospective randomised trial of early dietary protein restriction in chronic renal failure. Lancet 1984;ii: 1291-5.

11 El Nahas AM, Masters-Thomas A, Brady SA, et al. Selective effect of low protein diets in chronic renal diseases. $B r M e d$ f 1984;289:1337.

12 Maroni BJ, Steinman TI, Mitch WE. A method for estimating nitrogen intake of patients with chronic renal failure. Kidney Int 1985;27:58-65.

13 Isaksson B. Urinary nitrogen output as a validity test in dietary surveys. Am f Clin Nutr 1980;33: 4-12.

14 Baker JR, O'Connor JP, Metcalf PA, Lawson MR, Johnson RN. Clinical usefulness of estimation of serum fructosamine concentration as a screening test for diabetes mellitus. $\mathrm{Br} \mathrm{Med} \mathrm{J}$ 1983;287:863-7.

15 Wiseman MJ, Saunders AJ, Keen H, Viberti GC. Effect of blood glucose control on increased glomerular filtration rate and kidney size in insulin-dependent diabetes. $N$ Engl f $\mathrm{Med}$ 1985;312:617-21.

16 Rasmussen SN, Haase L, Kjeldson H, Hancke S. Determination of renal volume by ultrasound scanning. $\mathcal{}$ CU $1978 ; 6: 160-4$

17 Wiseman MJ, Viberti GC, Keen H. Threshold effect of plasma glucose in the glomerular hyperfiltration of diabetes. Nephron 1984;38:257-60.

$18 \mathrm{Keen} \mathrm{H}$, Chlouverakis $\mathrm{C}$. An immunoassay method for urinary albumin at low concentrations. Lancet 1963;ii:913-6.

19 Kaysen GA, Gambertoglio J, Jimenez I, Jones H, Hutchinson FN. Effect of dietary protein intake on albumin homeostasis in nephrotic patients. Kidney Int 1986;29:572-7.
20 Viberti GC, Bilous RW, Pickup JC, Keen H. Proteinuria in diabetes mellitus. Role of spontaneous and experimental variation in glycaemia. Kidney Int 1982;21:714-20.

21 Parving H-H, Noer I, Deckert T, et al. The effect of metabolic regulation on microvascular permeability to small and large molecules in short-term diabetes. Diabetologia 1976;12:161-6.

22 Wiseman MJ, Viberti GC, Mackintosh D, Jarrett RJ, Keen H. Glycaemia, arterial pressure and microalbuminuria in type I (insulin-dependent) diabetes mellitus. Diabetologia 1984;26:401-5.

23 Parving H-H, Andersen AR, Smidt UM, Svendsen PA. Early aggressive antihypertensive treatment reduces rate of decline in kidney function in diabetic nephropathy. Lancel 1983;i:1176-8.

24 Moorhead JF, Chan MK, El-Nahas M, Varghese Z. Lipid nephrotoxicity in chronic progressive glomerular and tubulointerstitial disease. Lancet 1982;ii:1309-11.

25 Bergstrom J. Discovery and rediscovery of low protein diets. Clin Nephrol 1984;21:29-35.

26 Barsotti G, Giannoni E, Morelli E, et al. The decline of renal function slowed by very low phosphorus intake in chronic renal patients following a low nitrogen diet. Clin Nephrol 1984;21:54-9.

27 Zatz R, Meyer TW, Rennke HG, Brenner BM. Predominance of hemodynamic rather than metabolic factors in the pathogenesis of diabetic glomerulopathy. Proc Natl Acad Sci USA 1985;82:5963-7.

28 Giordano C, Capodicasa G, De Santo NG. Effects of various diets on the progression of human and experimental uraemia. Proceedings of European Dialysis and Transplant Association-Europea Renal Association 1984;21:549-57.

29 Peterson PA, Evrin PE, Berggard I. Differentiation of glomerular tubular and normal proteinuria Determination of urinary excretion of $\beta_{2}$ microglobulin, albumin, and total protein. $\mathcal{f} \mathrm{Clin}$ Invest 1969;48:1189-98.

30 Rasch R. Prevention of diabetic glomerulopathy in streptozotocin-diabetic rats by insulin treatment. Kidney size and glomerular volume. Diabetologia 1979;16:125-8.

31 Christiansen JS, Gammelgaard J, Tromir B, Svendsen PA, Parving H-H. Kidney function and size in diabetics before and during initial insulin treatment. Kidney Int 1982;21:683-8.

32 Seyer-Hansen K. Renal hypertrophy in streptozotocin-diabetic rats. Clin Sci 1976;51:551-5.

33 Elias H, Hennig A. Stereology of the human renal glomerulus. In: Weibel E, Elias H, eds. Quantitative methods in morphology. Berlin: Springer-Verlag, 1967:130-66.

34 Home PD, Marshall SM. Problems and safety of continuous subcutaneous insulin infusion. Diabetic Medicine 1984;1:41-4.

35 Mecklenburg RS, Benson EA, Benson JW. Acute complications associated with insulin infusion pump therapy. JAMA 1984;252:3265-9.

36 Tindall H, Hopper AH, Davies JA. Progression of microalbuminuria in patients with type 1 diabetes mellitus and hypertension is halted by atenolol [Abstract]. Diabetic Medicine 1986;3:382A.

37 Christensen CK, Mogensen CE. Reversal of progression in renal albumin excretion in incipien diabetic nephropathy by antihypertensive treatment. [Abstract.] Diabetes Research and Clinical Practice 1985;1(suppl 1):S100.

38 El Nahas AM, Coles GA. Dietary treatment of chronic renal failure: ten unanswered questions. Lancet 1986;: $597-600$.

(Accepted 23 January 1987)

\title{
Bone mineral density in Addison's disease: evidence for an effect of adrenal androgens on bone mass
}

\author{
J P DEVOGELAER, J CRABBÉ, C NAGANT DE DEUXCHAISNES
}

\begin{abstract}
It is unknown whether replacement doses of cortisone acetate and the absence of the small amounts of androgens secreted by the adrenal cortex may cause osteoporosis. This was studied in 35 patients (12 men and 23 women) suffering from primary adrenocortical failure and taking cortisone acetate $25.37 .5 \mathrm{mg}$ and fludrocortisone 50-100 $\mu \mathrm{g}$ daily. Bone mineral density was measured by single photon absorptiometry at the midshaft of the radius, representing cortical bone, and at the distal part of the radius, a site with a significant trabecular component. The bone mineral density was normal in premenopausal female patients as well as in male patients, showing that replacement doses of cortisone acetate do not affect bone mass. By contrast, in postmenopausal patients there was a dramatic bone loss in
\end{abstract}

Department of Medicine, St-Luc University Hospital, Louvain University, 1200 Brussels, Belgium

J P DEVOGELAER, MD, associate head, rheumatology clinic

J CRABBÉ, MD, professor of endocrinology

C NAGANT DE DEUXCHAISNES, MD, professor of rheumatology

Correspondence to: Dr Devogelaer. addition to the physiological postmenopausal decrease in bone mass.

This loss, combined with the low plasma concentrations of androstenedione, dehydroepiandrosterone, and testosterone (and low concentrations of oestrone of adrenal origin), indicates that adrenal androgens may be essential for the maintenance of bone mass in postmenopausal women with Addison's disease. In addition, these data indicate that the small amounts of androgens secreted by the adrenal cortex have a role in the maintenance of bone mass in normal postmenopausal women.

\section{Introduction}

It is well known that supraphysiological amounts of glucocorticoids may induce osteoporosis. The question whether physiological doses of glucocorticoids are devoid of this side effect has not been settled, however, as we have discussed elsewhere with regard to rheumatoid arthritis. ${ }^{1}$ As rheumatoid arthritis may influence peripheral bone mass we sought to resolve this problem by studying patients suffering from primary adrenocortical failure (Addison's disease) and receiving treatment with glucocorticoid substitutes. At the same time we investigated whether the adrenal androgens played a part in the maintenance of bone mass. 